\title{
$\not{Z s} \mathfrak{e} \mathfrak{i} \mathfrak{i} \circ \mathfrak{x}$ t.
}

Dá bieje (Bebidte fid in bie S̈ffentlidfeit wagen, ge= fajiegt nur, weil vielfeitige arufforberung bazu ergangen ift, und zwar von jolder Seite, bie nidft unbeaditet bleiben burfte. Die Didterin felbit ift biel zu bejdeiben, baran zu benten.

Bielleiđt tommen fie abfintslos einem Bedürfnis entgegen, bas fajon hier und ba empfunden worben ift. ES fehlt für ben Unterridt in ber Bsejhidte, insbejondere an ben Tönteridulen,

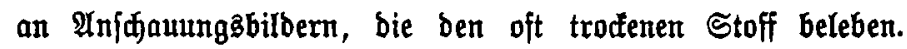
Nun giebt ez ja Bebinte, weit beffere, als bie vorliegenden, bie biejen Bmed̃ erfüllen; aber folder, bie ohne weiteres ben Mäbden in bie şand gegeben, auf allen Stufen zum Bortrag gebradjt und gelernt werben tönnen, finb es nidjt alla viele.

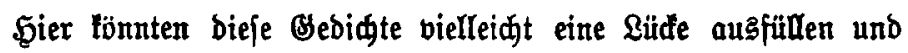
einen Dienft Leiften.

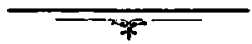


